\title{
Data report: occurrence of age-diagnostic nannofossil and biostratigraphic datums at IODP Expedition 316 Sites C0004 and C0008, Nankai Trough'
}

\author{
$\mathrm{Xin} \mathrm{Su}^{2}$
}

\section{Chapter contents}

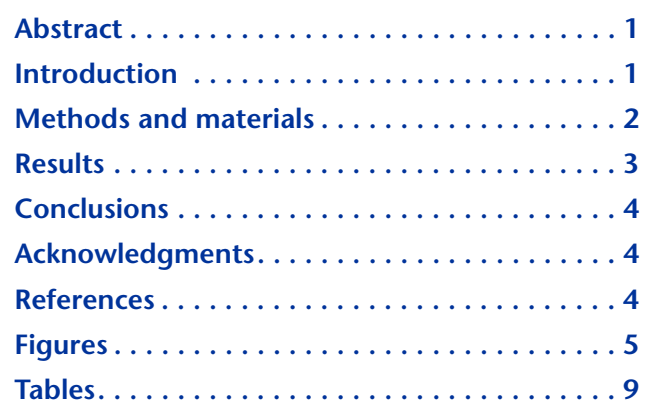

${ }^{1}$ Su, X., 2012. Data report: occurrence of agediagnostic nannofossil and biostratigraphic datums at IODP Expedition 316 Sites C0004 and C0008, Nankai Trough. In Kinoshita, M., Tobin, H., Ashi, J., Kimura, G., Lallemant, S., Screaton, E.J., Curewitz, D., Masago, H., Moe, K.T., and the Expedition 314/315/316 Scientists, Proc. IODP, 314/315/316: Washington, DC (Integrated Ocean Drilling Program Management International, Inc.). doi:10.2204/iodp.proc.314315316.210.2012 ${ }^{2}$ School of Marine Geosciences, China University of Geosciences (Beijing), Xueyuan Road 29, Beijing, 100083, China.xsu@cugb.edu.cn

\begin{abstract}
Preliminary structural and nannofossil observations from core materials at Integrated Ocean Drilling Program (IODP) Site C0004 indicate two age reversals and a complex history of deformation in the Nankai accretionary prism. In order to improve nannofossil biostratigraphy and provide more detailed age control for understanding this deformation history, Pliocene-Pleistocene calcareous nannofossils from sediments at Site C0004 and in IODP Hole C0008A were analyzed. This study presents the nannofossil range chart for Pliocene-Pleistocene age-diagnostic species and provides a detailed record of nannofossil events and zones for three holes. The record also revealed or confirmed the presence of a number of unconformities and/or age reversals in the sediment sequence at Site C0004, providing detailed age control for constraining faulting or folding intervals.
\end{abstract}

\section{Introduction}

Integrated Ocean Drilling Program (IODP) Expedition 316 is a part of the Nankai Trough Seismogenic Zone Experiment (NanTroSEIZE) complex drilling project, a coordinated multiexpedition drilling project with the purpose of investigating fault mechanics and seismogenesis along subduction megathrusts in the Nankai Trough (see the "Expedition 316 summary" chapter [Screaton et al., 2009]). During Expedition 316, four sites (C0004, C0006, C0007, and C0008) were drilled in the Nankai Trough (Fig. F1). IODP Site C0004 is located along the slope of the accretionary prism and landward of the inferred intersection of the megasplay fault zone with the seafloor (see the "Expedition 316 Site C0004" chapter [Expedition 316 Scientists, 2009a]). Drilling at this site was conducted to examine the youngest sediments on the slope overlying the accretionary prism, which consist of slowly deposited marine sediments and redeposited material from upslope (Fig. F2). IODP Site C0008 is located $\sim 1 \mathrm{~km}$ seaward of Site C0004 (Fig. F2) and was selected to examine the basin seaward of the splay fault penetrated at Site C0004 (see the "Expedition 316 Site C0008" chapter [Expedition 316 Scientists, 2009b]). The drilling results from Sites C0004 and C0008 also provided information necessary to explore the splay fault's origin and evolution and its relation to the structural evolution of the Nankai margin through time (Strasser et al., 2009). 
The objective of this study is to provide detailed data regarding the occurrence of age-diagnostic calcareous nannofossils and to obtain better resolved biostratigraphic datums for these two sites, through reexamining shipboard nannofossil slides and data and analyzing additional samples during the postcruise study.

\section{Methods and materials}

\section{Sites and samples}

Pliocene-Pleistocene calcareous nannofossils from sediments at Site C0004 and in Hole C0008A in the Nankai Trough were analyzed. Downcore sample spacing is about $\sim 150$ to $\sim 300 \mathrm{~cm}$; however, additional samples were analyzed for intervals where a biostratigraphic event horizon was located based on initial shipboard analysis.

\section{Site C0004}

Two holes were drilled at Site C0004 on the shallow portion of the megasplay fault system during Expedition 316. Hole C0004C $\left(33^{\circ} 13.2278^{\prime} \mathrm{N}\right.$, $136^{\circ} 43.3312^{\prime} \mathrm{E}$; water depth $=2627.0 \mathrm{~m}$ ) was cored from the seafloor to 134.97 meters below seafloor (mbsf), through the slope sediments into the upper part of the accretionary prism; and Hole C0004D $\left(33^{\circ} 13.2190 \mathrm{~N}, 136^{\circ} 43.3287^{\prime} \mathrm{E}\right.$, water depth $\left.=2630.5 \mathrm{~m}\right)$ was cored from 100 to $398.79 \mathrm{mbsf}$, from the upper part of the accretionary prism and across its lower boundary into the sediments below (see the "Expedition 316 Site C0004" chapter [Expedition 316 Scientists, 2009a]). Nannofossils from these two holes were analyzed.

\section{Site $\mathrm{C0008}$}

Three holes (C0008A, C0008B, and C0008C) were drilled at Site C0008. Hole C0008A $\left(33^{\circ} 12.8229^{\prime} \mathrm{N}\right.$, $136^{\circ} 43.5997^{\prime} \mathrm{E}$; water depth $\left.=2751 \mathrm{~m}\right)$ was cored from the seafloor to $272.46 \mathrm{~m}$ (see the "Expedition 316 Site C0008" chapter [Expedition 316 Scientists, $2009 \mathrm{~b}])$. This hole recovered the longest sediment sequence and was selected for biostratigraphic analysis.

\section{Preparation and observation}

Standard smear slides were made for all samples. In addition, a concentration method was applied to obtain more nannofossils from fine sand or silt samples before making smear slides. About 1-3 g sediment were put in a beaker with distilled water and stirred for several seconds to suspend samples. The suspension was left sitting for a few minutes so that sandsized particles settled to the bottom first, and nanno- fossils were concentrated in the upper part of the suspension, from which several drops were taken to make smear slides.

Calcareous nannofossils were examined under crossed polarizers and transmitted light at $500 x-$ 1000× magnification using a Zeiss Axio Scope A1 in the micropaleontological laboratory of the School of Marine Geosciences, China University of Geosciences (Beijing).

The degrees of preservation of calcareous nannofossil species were noted as follows:

VG = very good preservation (no evidence of dissolution and/or overgrowth).

$\mathrm{G}$ = good preservation (slight dissolution and/or overgrowth; specimens are identifiable to the species level).

$\mathrm{M}$ = moderate preservation (exhibit some etching and/or overgrowth; most specimens are identifiable to the species level).

$\mathrm{P}=$ poor preservation (severely etched or with overgrowth; most specimens cannot be identified at the species and/or generic level).

Group abundance (at 250× magnification) and relative abundance of individual species (at 1000x magnification) are estimated based on a seven-category scheme:

$$
\begin{aligned}
\mathrm{D}= & \text { dominant }(>50 \% \text { or }>50 \text { specimens per field of } \\
& \text { view }[\mathrm{FOV}]) . \\
\mathrm{A}= & \text { abundant }(15 \%-50 \% \text { or } 10-50 \text { specimens per } \\
& \text { FOV }) . \\
\mathrm{C}= & \text { common }(5 \%-15 \% \text { or } 1-10 \text { specimens per } \\
& \text { FOV }) . \\
\mathrm{F}= & \text { few } / \text { frequent }(1 \%-5 \% \text { or }>1 \text { specimen per } 1-10 \\
& \text { FOVs }) . \\
\mathrm{R}= & \text { rare }(<1 \% \text { or }>1 \text { specimen per } 20 \text { FOVs }) . \\
\mathrm{T}= & \text { trace }(<0.1 \% \text { or }<1 \text { specimen per } 20 \text { FOVs }) . \\
\mathrm{B}= & \text { barren }(0 ; \text { this level is used only for group } \\
& \text { abundance }) .
\end{aligned}
$$

\section{Biostratigraphic zonations and timescales}

The Neocene timescale followed Lourens et al., (2004). The biostratigraphic zonation of calcareous nannofossils is based upon the schemes of Martini (1971) and Okada and Bukry (1980), modified by Young (1998). The orbitally turned ages for biostratigraphic datums were compiled mainly from Raffi et al. (2006).

A summary of the timescale and nannofossil zones used in this study is given in Figure F3 and Table T1.

\section{Taxonomic remarks}

Several species of genus Gephyrocapsa are commonly used as Quaternary biostratigraphic markers. The Ge- 
phyrocapsa species show a wide range of variation in sizes and other morphological features, causing problems in identification (Su, 1996). Size-defined morphological groups of this genus, suggested by Young (1998) (i.e., Gephyrocapsa spp. medium [>3.5 $\mu \mathrm{m}]$, Gephyrocapsa spp. medium I [ $>3.5-<4 \mu \mathrm{m}]$, Gephyrocapsa spp. medium II $[\geq 4.5-<5.5 \mu \mathrm{m}]$, and Gephyrocapsa spp. large $[\geq 5.5 \mu \mathrm{m}]$ ), were used during shipboard and shore-based studies. Reticulofenestra pseudoumbilicus is identified by reticulofenestrid specimens having a maximum coccolith length $>7$ $\mu \mathrm{m}$ in its uppermost range (lower Pliocene), after Young (1998). Identification of other calcareous nannofossils mainly followed the compilation of PerchNielsen (1985).

\section{Results}

Range charts of age-diagnostic nannofossil species for Holes C0004C, C0004D, and C0008A are given in Tables T2, T3, and T4.

\section{Site $\mathrm{C0004}$}

In Hole C0004C, a total of 14 nannofossil biostratigraphic events were recognized (Table T5). Three inconsecutive nannofossil zones were distinguished: Pleistocene Zones NN21 and NN19 and middle Pliocene Zone NN16, indicating the presence of unconformities between Zones NN21 and NN19 and between Zones NN19 and NN16.

A total of 16 nannofossil events were recognized for age and depth correlation in Hole C0004D (Table T6). The upper part (from the top of the hole to 255.27 mbsf) was assigned to Zones NN16, NN15NN14, and NN13 of early-middle Pliocene age. The middle part of this hole (259.53-291.05 mbsf) was characterized by two Zone NN16 intervals sandwiched by a Zone NN15-NN14 interval. The lower part of Hole C0004D (from 312.16 mbsf to the bottom of the hole) was assigned to early Pleistocene Zone NN19.

The biostratigraphic results for Site C0004 are correlated to lithology, log interpretation, and core recovery, and are summarized in Figure F4A. This correlation suggests that Units II and III defined for the prism sediments in the megasplay fault system are of early-middle Pliocene age (Zones NN16, NN15NN14, and NN13), whereas sediments above and below the prism are Pleistocene age (i.e., upper Pleistocene sediments lie above the prism and lower Pleistocene sediments lie below it). The lowermost sediments at this site are $<1.67 \mathrm{Ma}$, according to the presence of Gephyrocapsa spp. medium I $(>3.5-<4$ $\mu \mathrm{m})$; however, the presence of Zone NN19 sediments below Zone NN16 sediments at the bottom of the hole as well as the presence of multiple nannofossil zone repetitions and age reversals implies significant disturbances of the sedimentary sequence in the area, likely due to accretionary prism formation and subsequent disruption.

\section{Site $\mathbf{C 0 0 0 8}$}

For Hole C0008A, 17 nannofossil events were recognized (Table T7). The upper part (from the top of the hole to 241.78 mbsf) is Pleistocene age (Zones NN21 and NN19), whereas the lower part is middle-late Pliocene age, containing Zones NN18, NN17, and NN16.

The correlation of these zones with lithology, log interpretation, and core recovery for this hole are summarized in Figure F4B. The data are interpreted to indicate that most of Unit I is of Pleistocene age (Zones NN21 and NN19), and the lowest part of Unit I and Unit II are of late Pliocene age (Zones NN18, NN17, and NN16). The bottom sediments in this hole are $<3.65 \mathrm{Ma}$, according to the absence of Sphenolithus spp.

\section{Biostratigraphic correlation between sites}

Figure $\mathbf{F} 4$ shows the correlation of zones and important nannofossil events between Site C0004 and Hole C0008A. The correlation of two Pleistocene nannofossil events, first occurrence of Gephyrocapsa spp. large $(\geq 5.5 \mu \mathrm{m}, 1.56 \mathrm{Ma})$ and last occurrence Calcidiscus macintyrei ( $>11 \mu \mathrm{m}, 1.60 \mathrm{Ma})$, between Site C0004 and Hole C0008A indicates most of Unit II (75.94-312.16 mbsf) (Tables T4, T5) at Site C0004 is heavily faulted and that the faulting probably occurred roughly between 1.60 and $1.56 \mathrm{~m}$.y. The faulted interval at Site C0004 can be further subdivided into an upper part (75.94-255.27 mbsf) with a normal and relatively intact and continuous zone sequence (Zones NN16, NN15-NN14, and NN13), and a lower part (259.53-291.05 mbsf) characterized by common faults, missing intervals, disruptions, and age reversals. Although further investigation would be required to more completely delineate these different intervals and to illuminate the detailed nannofossil sequence, the data can be interpreted to represent the influence of (1) uplift of the accretionary prism (the upper part of the faulted section) and (2) disruption of the uplifted prism by splay faulting or out-of-sequence thrusting (the lower, more intensely disrupted part of the faulted section). This sequence of events parallels that interpreted based on Strasser et al. (2009). 


\section{Conclusions}

In conclusion, this study presents the range chart of Pliocene-Pleistocene age-diagnostic nannofossils and provides better resolved nannofossil datums and zones for Site C0004 and Hole C0008A.

At Site C0004, Unit II and III prism sediments in the megasplay fault system are of early-middle Pliocene age (Zones NN16, NN15-NN14, and NN13); sediments above and below the prism are Pleistocene age (upper Pleistocene sediments lie above the prism and lower Pleistocene sediments below it). In Hole C0008A, the majority of Unit I is of Pleistocene age (Zones NN21 and NN19), and the lowest part of Unit I and Unit II are of late Pliocene age (Zones NN18, NN17, and NN16).

Biostratigraphic correlation between Site C0004 and Hole C0008A suggests that most of Unit II at Site C0004 comprises faulted sediments and that faulting probably occurred roughly between 1.60 and 1.56 m.y. The faulted interval can subdivided into two parts: an upper part with normal zone sequence and a lower part characterized by common faults and age reversals. These two zones may correspond to uplift and subsequent disruption of the accretionary prism, similar to the interpretation of Strasser et al. (2009).

\section{Acknowledgments}

This research used samples and/or data provided by the Integrated Ocean Drilling Program (IODP). Two referees, Dr. Shijun Jiang and Dr. Dan Curewitz, provided comments and suggestions that substantially improved the quality of the manuscript. Funding for this research was provided by China Natural Sciences Foundation (grant number 40876030) and IODPChina.

\section{References}

Expedition 316 Scientists, 2009a. Expedition 316 Site C0004. In Kinoshita, M., Tobin, H., Ashi, J., Kimura, G., Lallemant, S., Screaton, E.J., Curewitz, D., Masago, H., Moe, K.T., and the Expedition 314/315/316 Scientists, Proc. IODP, 314/315/316: Washington, DC (Integrated Ocean Drilling Program Management International, Inc.). doi:10.2204/iodp.proc.314315316.133.2009

Expedition 316 Scientists, 2009b. Expedition 316 Site C0008. In Kinoshita, M., Tobin, H., Ashi, J., Kimura, G.,
Lallemant, S., Screaton, E.J., Curewitz, D., Masago, H., Moe, K.T., and the Expedition 314/315/316 Scientists, Proc. IODP, 314/315/316: Washington, DC (Integrated Ocean Drilling Program Management International, Inc.). doi:10.2204/iodp.proc.314315316.136.2009

Lourens, L., Hilgen, F., Shackleton, N.J., Laskar, J., and Wilson, D., 2004. The Neogene period. In Gradstein, F.M., Ogg, J.G., and Smith, A. (Eds.), A Geologic Time Scale 2004: Cambridge (Cambridge Univ. Press), 409-440. doi:10.2277/0521786738

Martini, E., 1971. Standard Tertiary and Quaternary calcareous nannoplankton zonation. In Farinacci, A. (Ed.), Proc. Second Planktonic Conf. Roma 1970: Rome (Ed. Tecnosci.), 2:739-785.

Okada, H., and Bukry, D., 1980. Supplementary modification and introduction of code numbers to the low-latitude coccolith biostratigraphic zonation (Bukry, 1973; 1975). Mar. Micropaleontol., 5:321-325. doi:10.1016/ 0377-8398(80)90016-X

Perch-Nielsen, K., 1985. Cenozoic calcareous nannofossils. In Bolli, H.M., Saunders, J.B., and Perch-Nielsen, K. (Eds.), Plankton Stratigraphy: Cambridge (Cambridge Univ. Press), 427-554.

Raffi, I., Backman, J., Fornaciari, E., Pälike, H., Rio, D., Lourens, L., and Hilgen, F., 2006. A review of calcareous nannofossil astrobiochronology encompassing the past 25 million years. Quat. Sci. Rev., 25(23-24):3113-3137. doi:10.1016/j.quascirev.2006.07.007

Screaton, E.J., Kimura, G., Curewitz, D., and the Expedition 316 Scientists, 2009. Expedition 316 summary. In Kinoshita, M., Tobin, H., Ashi, J., Kimura, G., Lallemant, S., Screaton, E.J., Curewitz, D., Masago, H., Moe, K.T., and the Expedition 314/315/316 Scientists, Proc. IODP, 314/315/316: Washington, DC (Integrated Ocean Drilling Program Management International, Inc.). doi:10.2204/iodp.proc.314315316.131.2009

Strasser, M., Moore, G.F., Kimura, G., Kitamura, Y., Kopf, A.J., Lallemant, S., Park, J.-O., Screaton, E.J., Su, X., Underwood, M.B., and Zhao, X., 2009. Origin and evolution of a splay fault in the Nankai accretionary wedge. Nat. Geosci., 2(9):648-652. doi:10.1038/ngeo609

$\mathrm{Su}, \mathrm{X} ., 1996$. Development of late Tertiary and Quaternary coccolith assemblages in the northeast Atlantic. GEOMAR-Rep., 48.

Young, J.R., 1998. Neogene. In Bown, P.R. (Ed.), Calcareous Nannofossil Biostratigraphy: Dordrecht, The Netherlands (Kluwer Academic Publ.), 225-265.

Initial receipt: 17 October 2010

Acceptance: 26 October 2011

Publication: 31 January 2012

MS 314315316-210 
Figure F1. Drilling area of IODP Expedition 316 in the Nankai Trough (see the "Expedition 316 summary" chapter [Screaton et al., 2009]). In inset, EP = Eurasian plate, PP = Pacific plate, NAP = North American plate, PSP $=$ Philippine Sea plate.

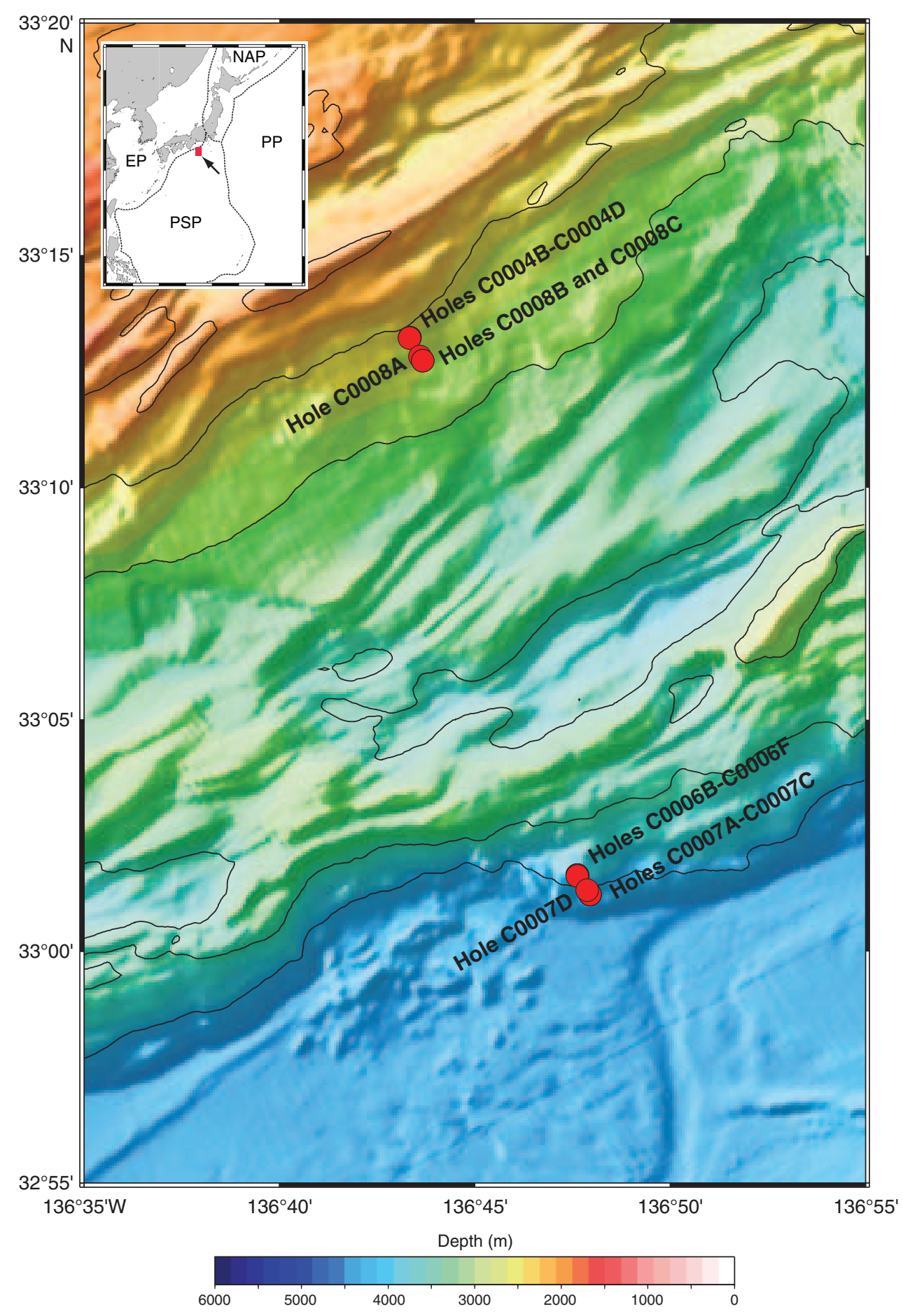


Figure F2. Location of IODP Expedition 316 sites in the Nankai Trough (see the "Expedition 316 summary" chapter [Screaton et al., 2009]). VE = vertical exaggeration.

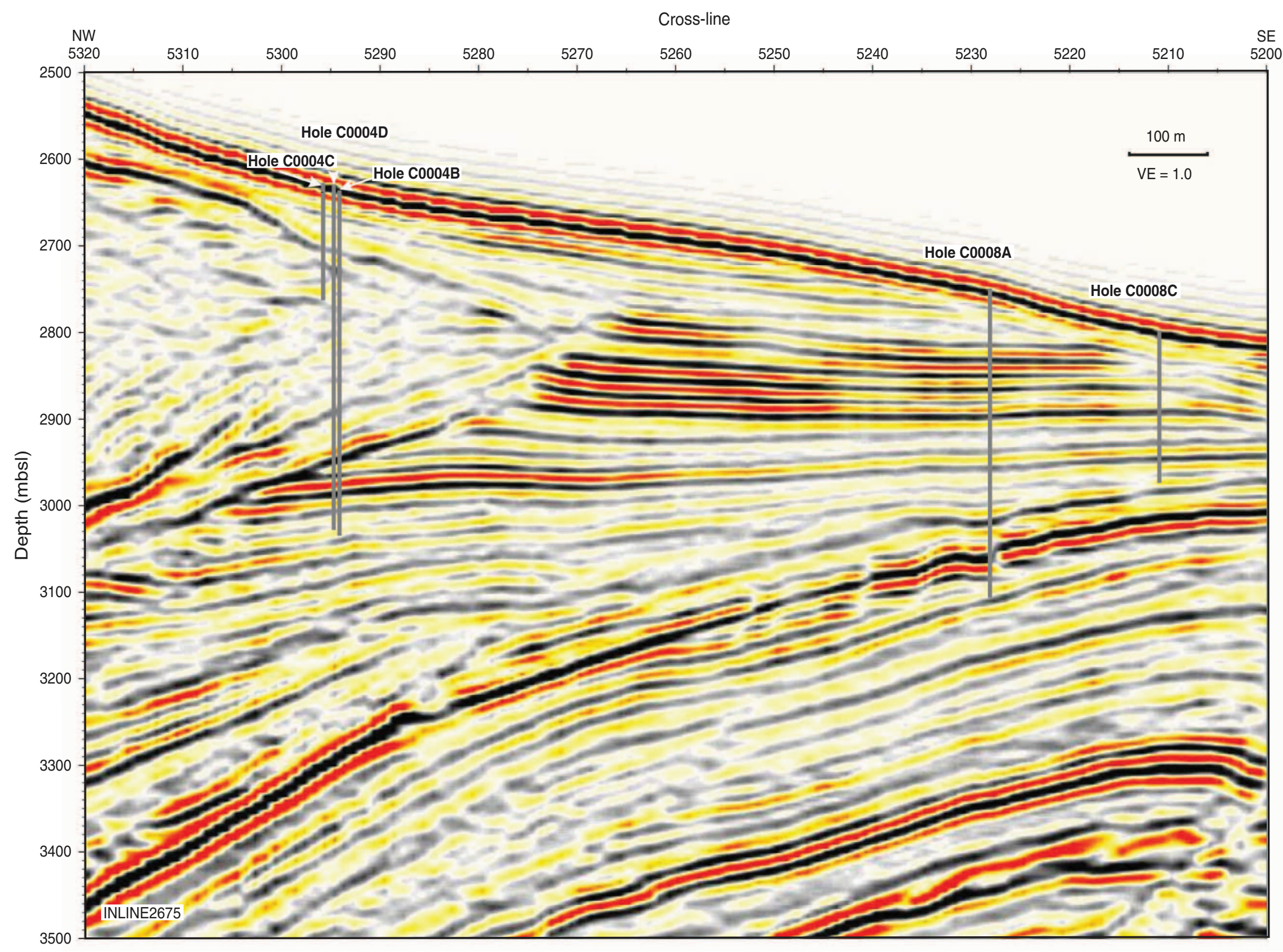


Figure F3. Pliocene-Pleistocene timescale and magnetostratigraphic and biostratigraphic events. FO = first occurrence, $\mathrm{LO}=$ last occurrence.

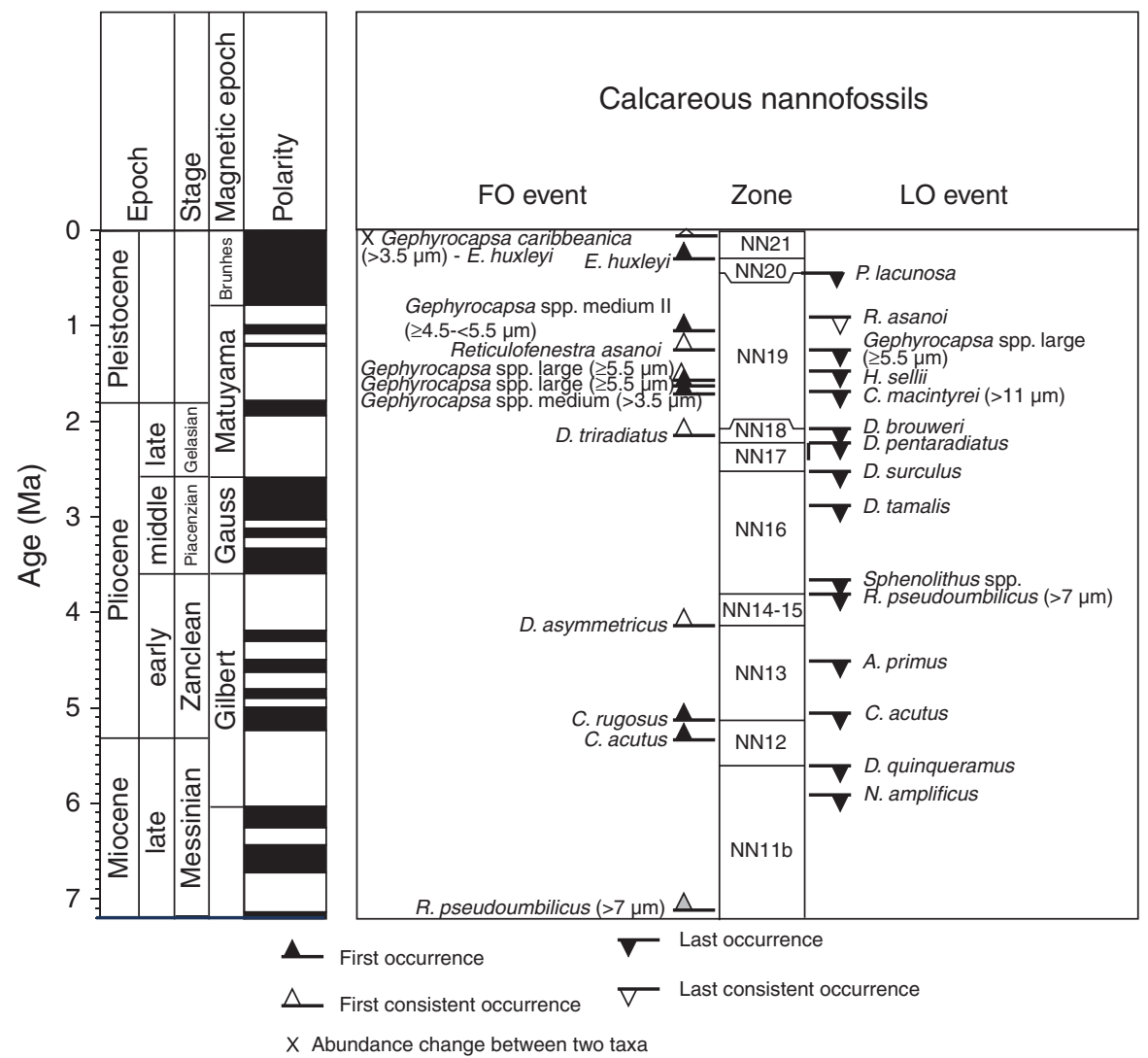


Figure F4. Correlation of calcareous nannofossil zones and important events between Site C0004 and Hole C0008A. A. Site C0004. B. Hole C0008A. See text for details. FO = first occurrence, LO = last occurrence.

A

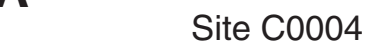

B

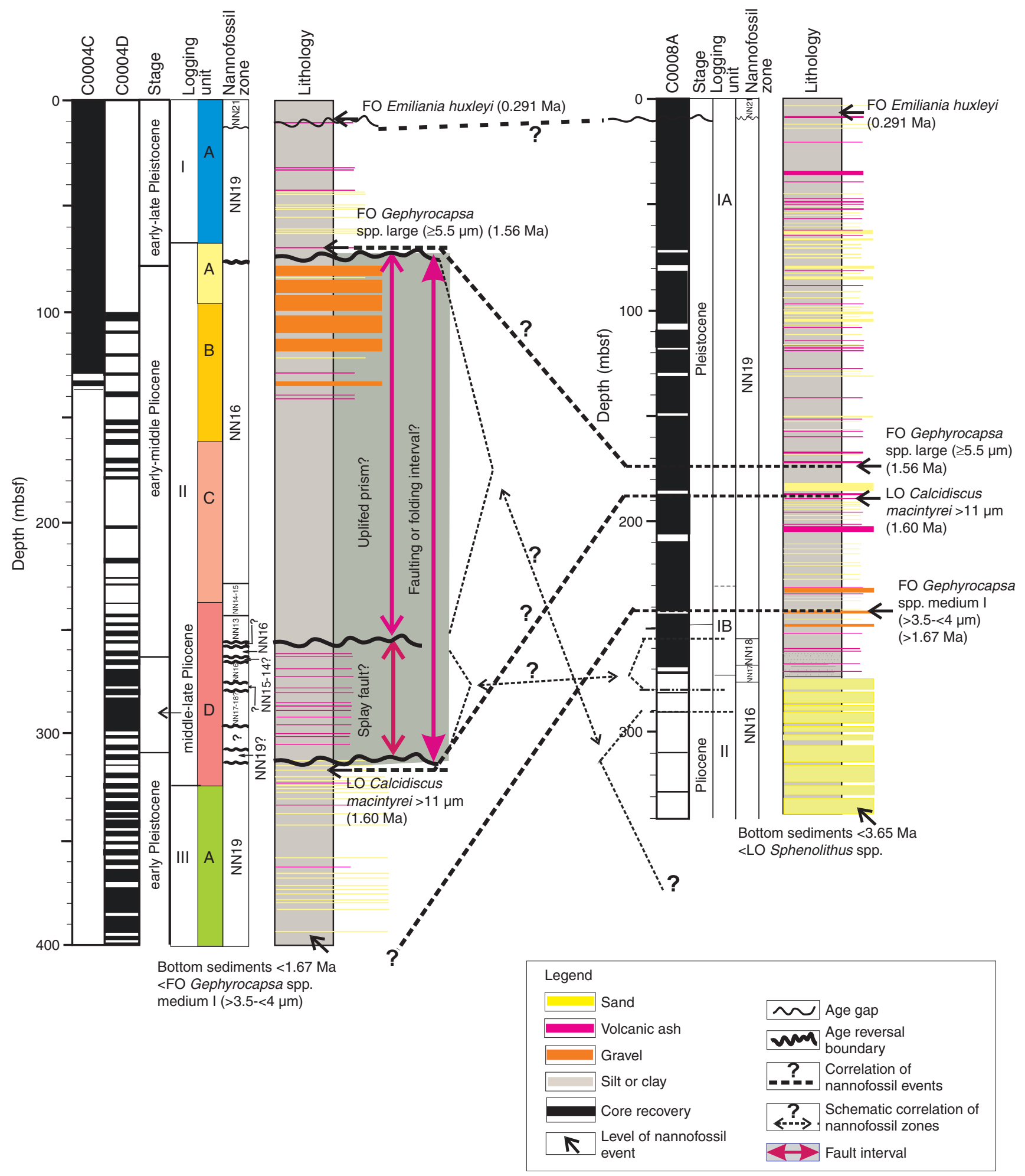


Table T1. Calcareous nannofossil events (based on Raffi et al., 2006, with slight modification) used as biostratigraphic tie points in this study.

\begin{tabular}{|c|c|c|}
\hline Taxon event & $\begin{array}{l}\text { Zone } \\
\text { (base) }\end{array}$ & $\begin{array}{l}\text { Age } \\
\text { (Ma) }\end{array}$ \\
\hline X Gephyrocapsa caribbeanica (>3.5 $\mu \mathrm{m})$ - Emiliania huxleyi & & 0.063 \\
\hline FO Emiliania huxleyi & NN21 & 0.291 \\
\hline LO Pseudoemiliania lacunosa & NN19 & 0.436 \\
\hline LCO Reticulofenestra asanoi & & 0.9 \\
\hline RE Gephyrocapsa spp. medium II $(\geq 4.5-<5.5 \mu \mathrm{m})$ & & 1.04 \\
\hline FCO Reticulofenestra asanoi & & $1.078^{*}$ \\
\hline LO Gephyrocapsa spp. large $(\geq 5.5 \mu \mathrm{m})$ & & 1.24 \\
\hline LO Helicosphaera sellii & & 1.34 \\
\hline FCO Gephyrocapsa spp. large $(\geq 5.5 \mu \mathrm{m})$ & & 1.46 \\
\hline FO Gephyrocapsa spp. large ( $\geq 5.5 \mu \mathrm{m})$ & & 1.560 \\
\hline LO Calcidiscus macintyrei (>11 $\mu \mathrm{m})$ & & 1.60 \\
\hline FO Gephyrocapsa spp. medium (>3.5 $\mu \mathrm{m})$ & NN19 & 1.67 \\
\hline LO Discoaster brouweri & NN18 & 2.06 \\
\hline AE Discoaster triradiatus & & 2.135 \\
\hline LO Discoaster pentaradiatus & NN17 & 2.393 \\
\hline LO Discoaster surculus & NN16 & 2.52 \\
\hline LO Discoaster tamalis & & 2.87 \\
\hline LO Sphenolithus spp. & & 3.65 \\
\hline LO Reticulofenestra pseudoumbilicus (>7 $\mu \mathrm{m})$ & NN15-NN14 & 3.79 \\
\hline FCO Discoaster asymmetricus & & 4.13 \\
\hline LO Amaurolithus primus & & 4.50 \\
\hline LO Ceratolithus acutus & & 5.04 \\
\hline FO Ceratolithus rugosus & NN13 & 5.12 \\
\hline FO Ceratolithus acutus & & 5.32 \\
\hline LO Discoaster quinqueramus & NN12 & 5.59 \\
\hline
\end{tabular}

* = datum based on Atlantic or Mediterranean records. $\mathrm{X}=$ crossover in abundance, $\mathrm{RE}=$ reentrance, $\mathrm{AE}=\mathrm{acme}$ end, $\mathrm{FO}=$ first occurrence, $\mathrm{FCO}$ $=$ first consistent occurrence, $\mathrm{LO}=$ last occurrence, $\mathrm{LCO}=$ last consistent occurrence. 
Table T2. Calcareous nannofossil range chart of age-diagnostic fossils, Hole C0004C. (Continued on next page.)

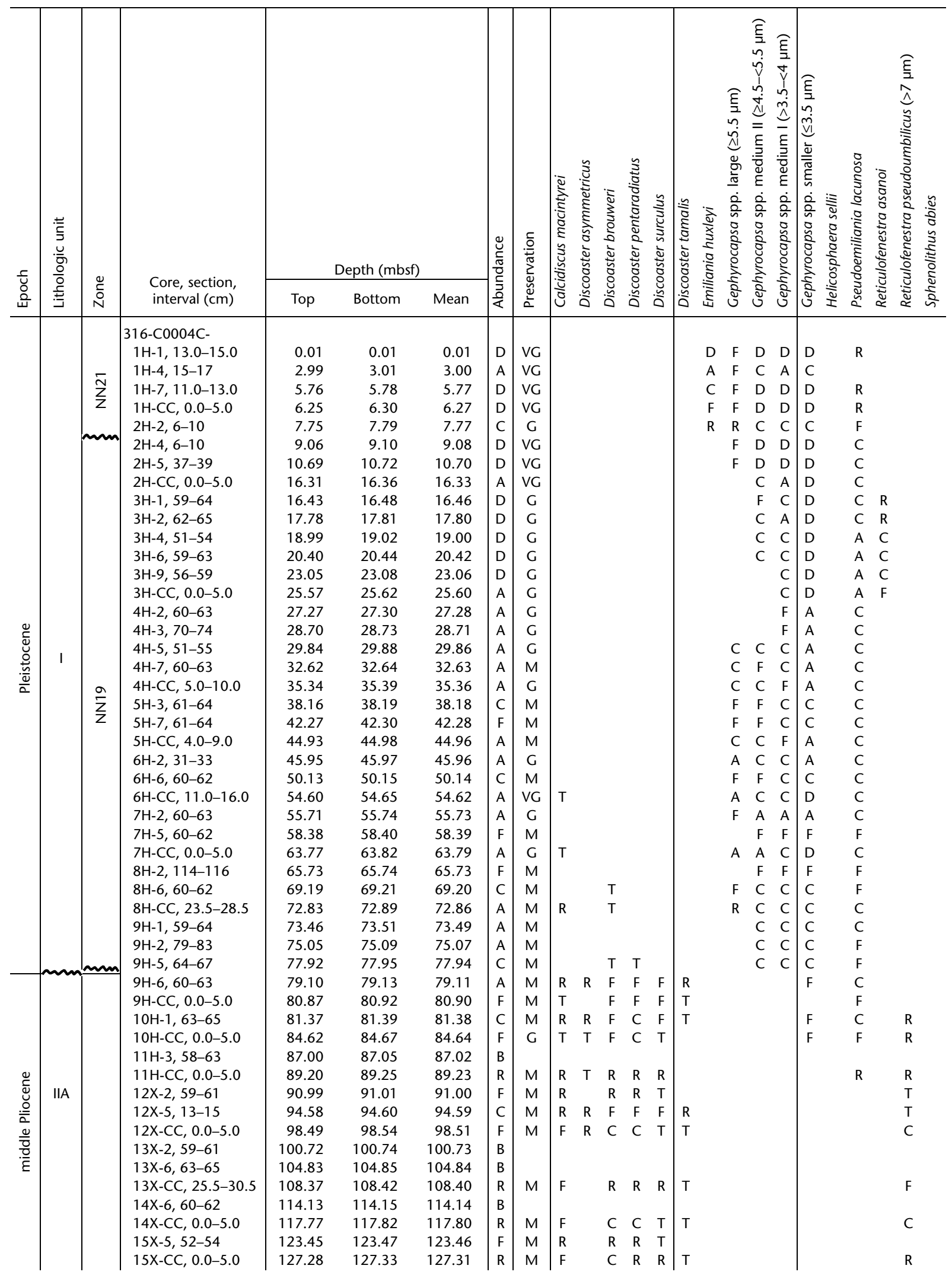


Table T2 (continued).

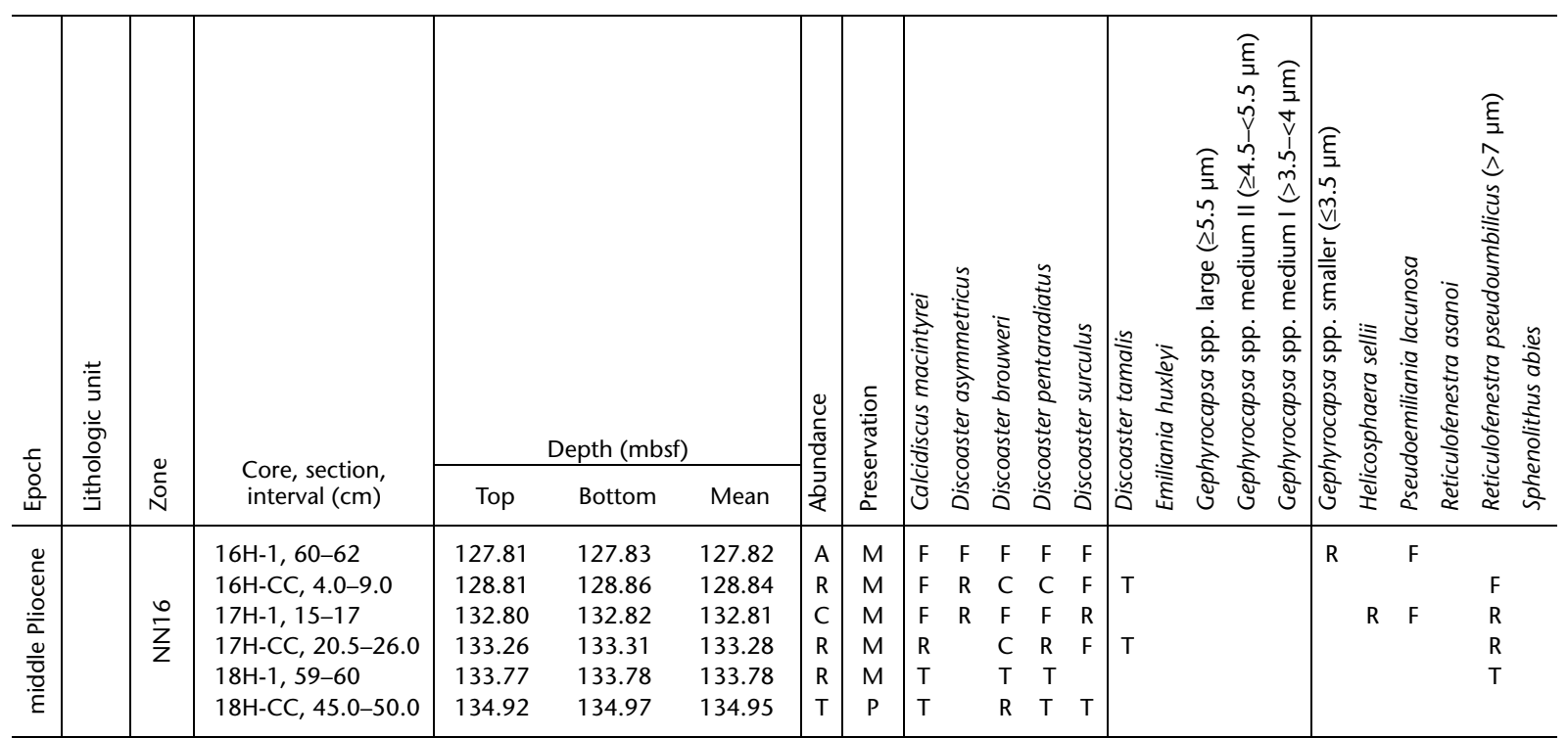

Abundance: $\mathrm{D}=$ dominant, $\mathrm{A}=$ abundant, $\mathrm{C}=$ common, $\mathrm{F}=$ few, $\mathrm{R}=$ rare $\mathrm{T}=$ trace $\mathrm{B}=$ barren. Preservation: $\mathrm{VG}=$ very good, $\mathrm{G}=\mathrm{good}, \mathrm{M}=$ moderate, $\mathrm{P}=$ poor. 


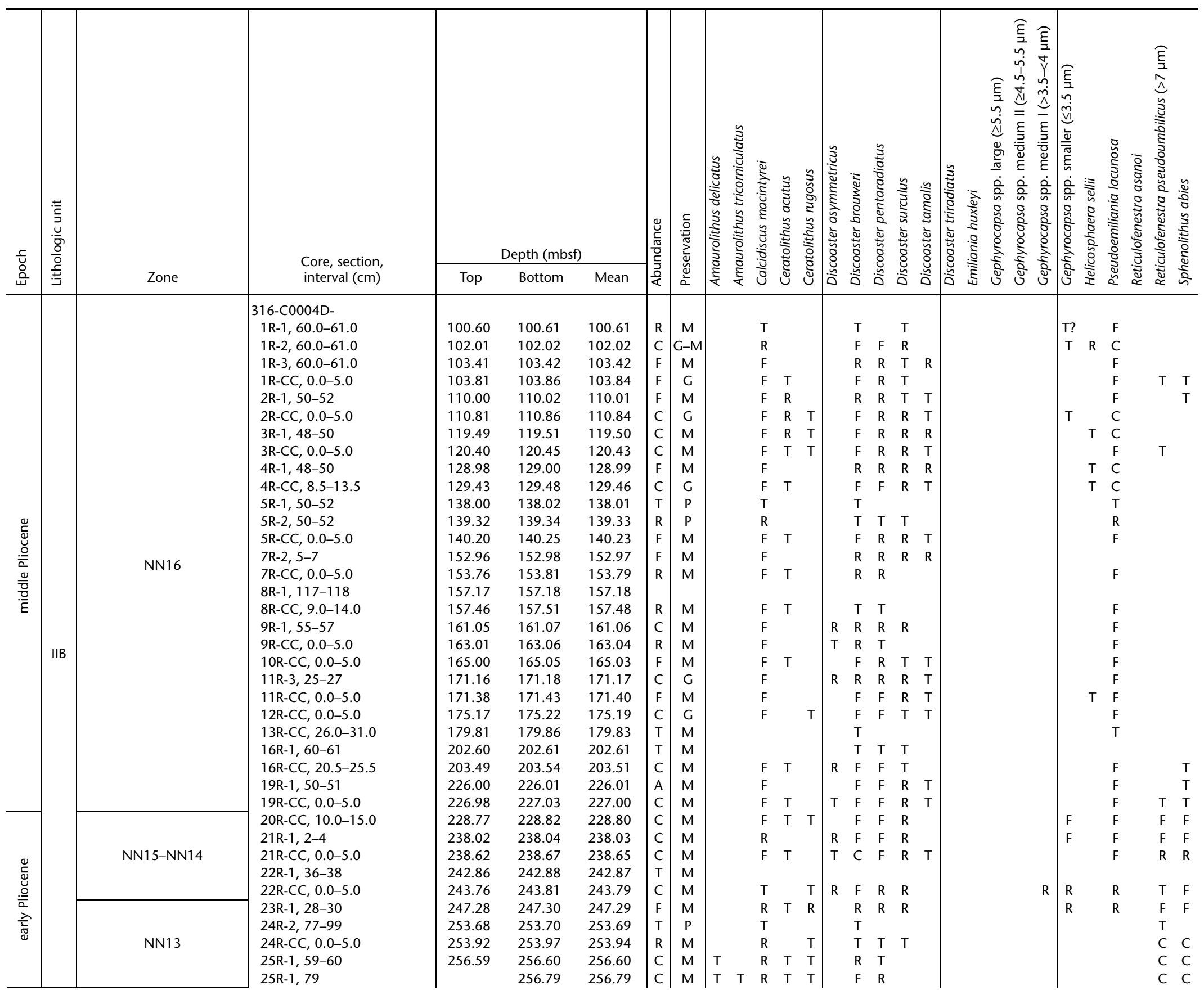


Table T3 (continued). (Continued on next page.)

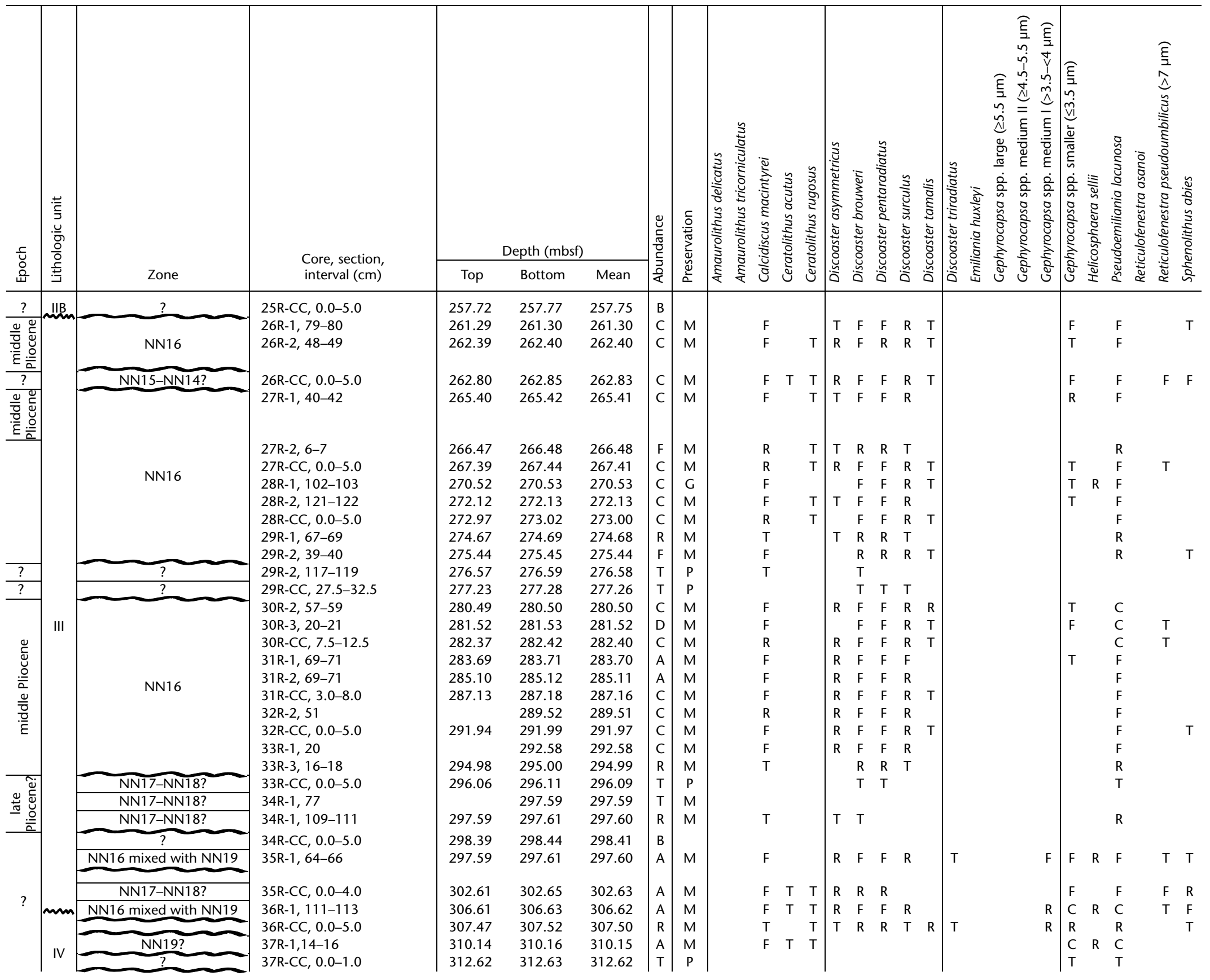




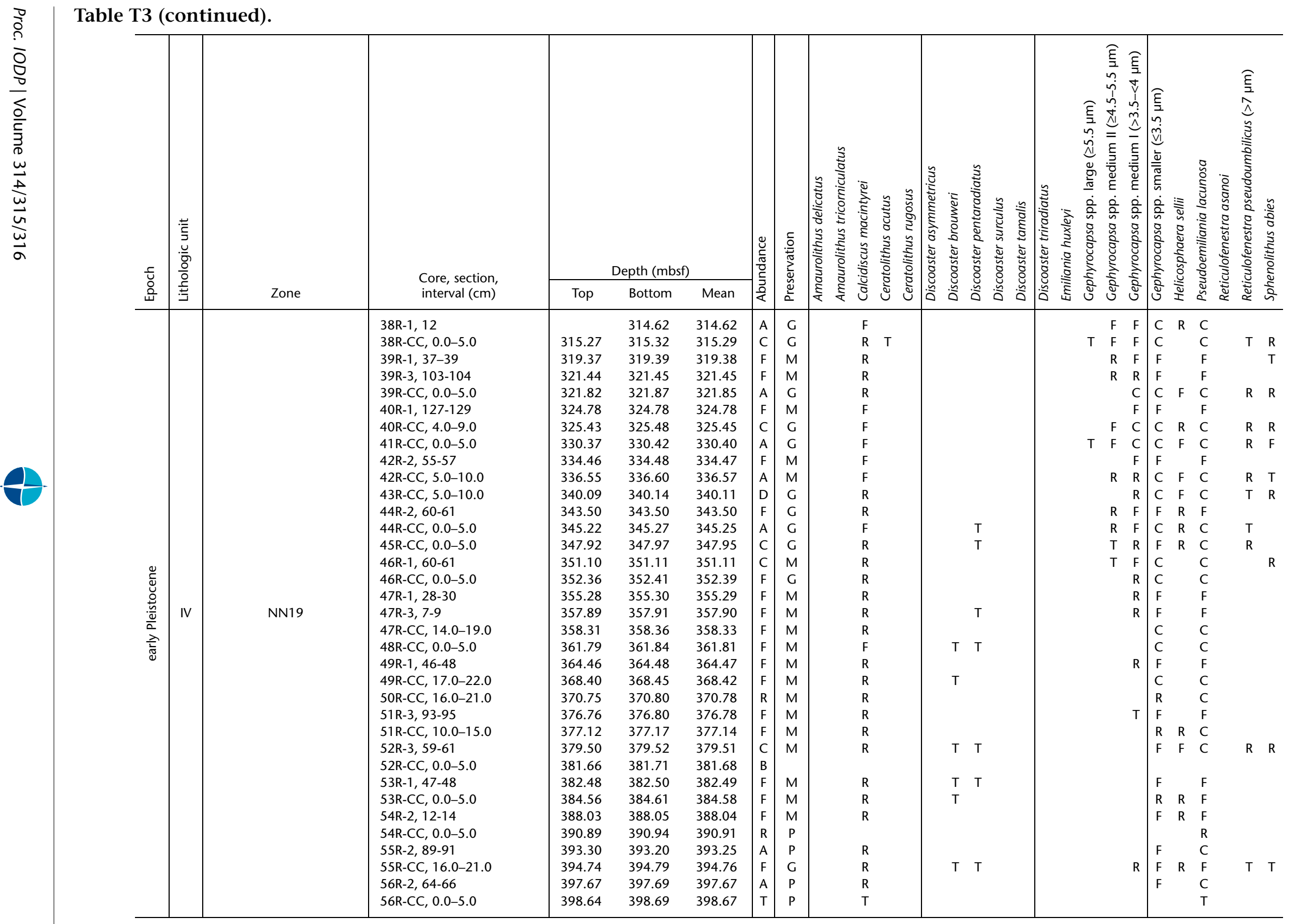


Table T4. Calcareous nannofossil range chart of age-diagnostic fossils, Hole C0008A. (Continued on next page.)

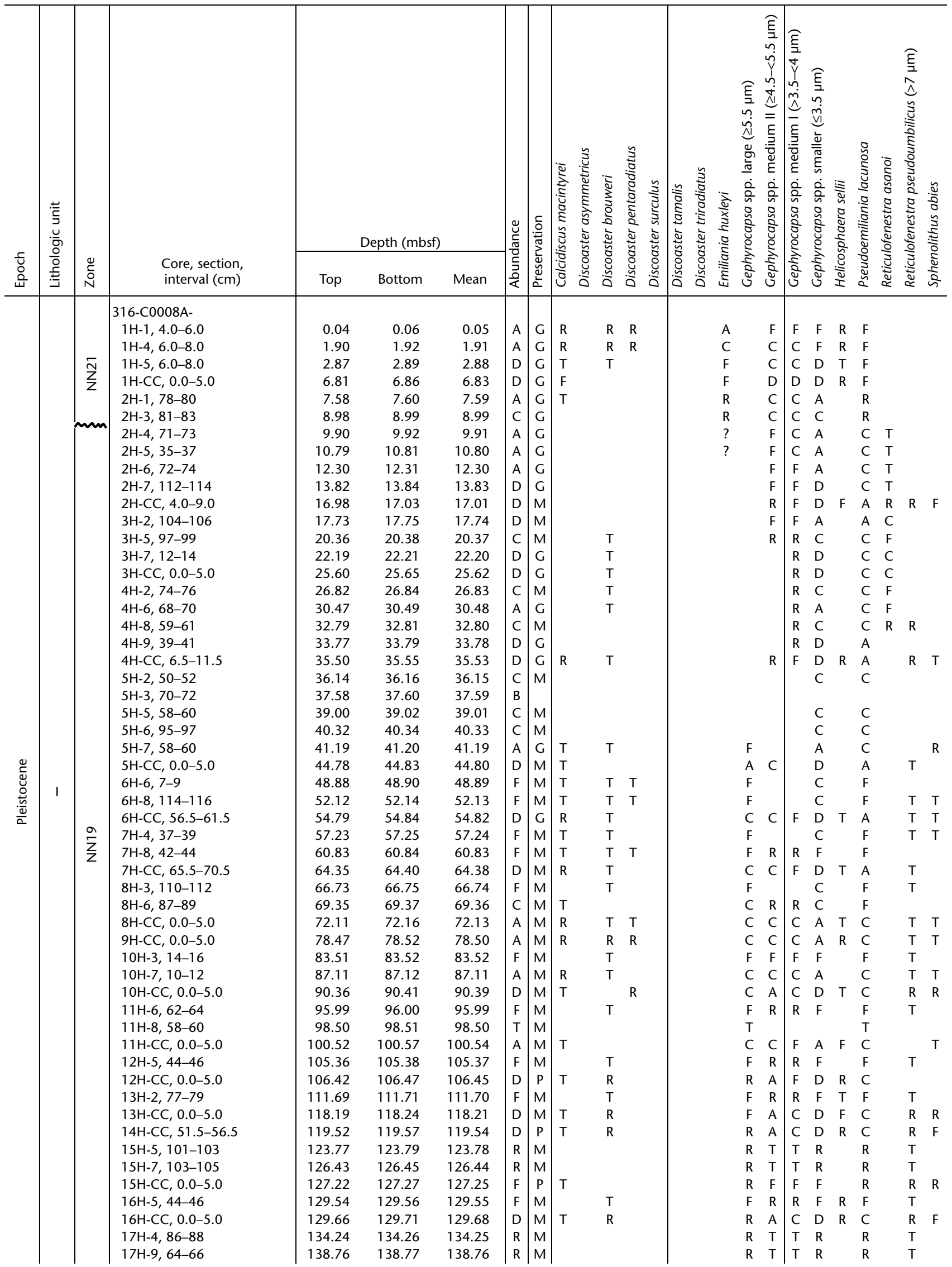


Table T4 (continued).

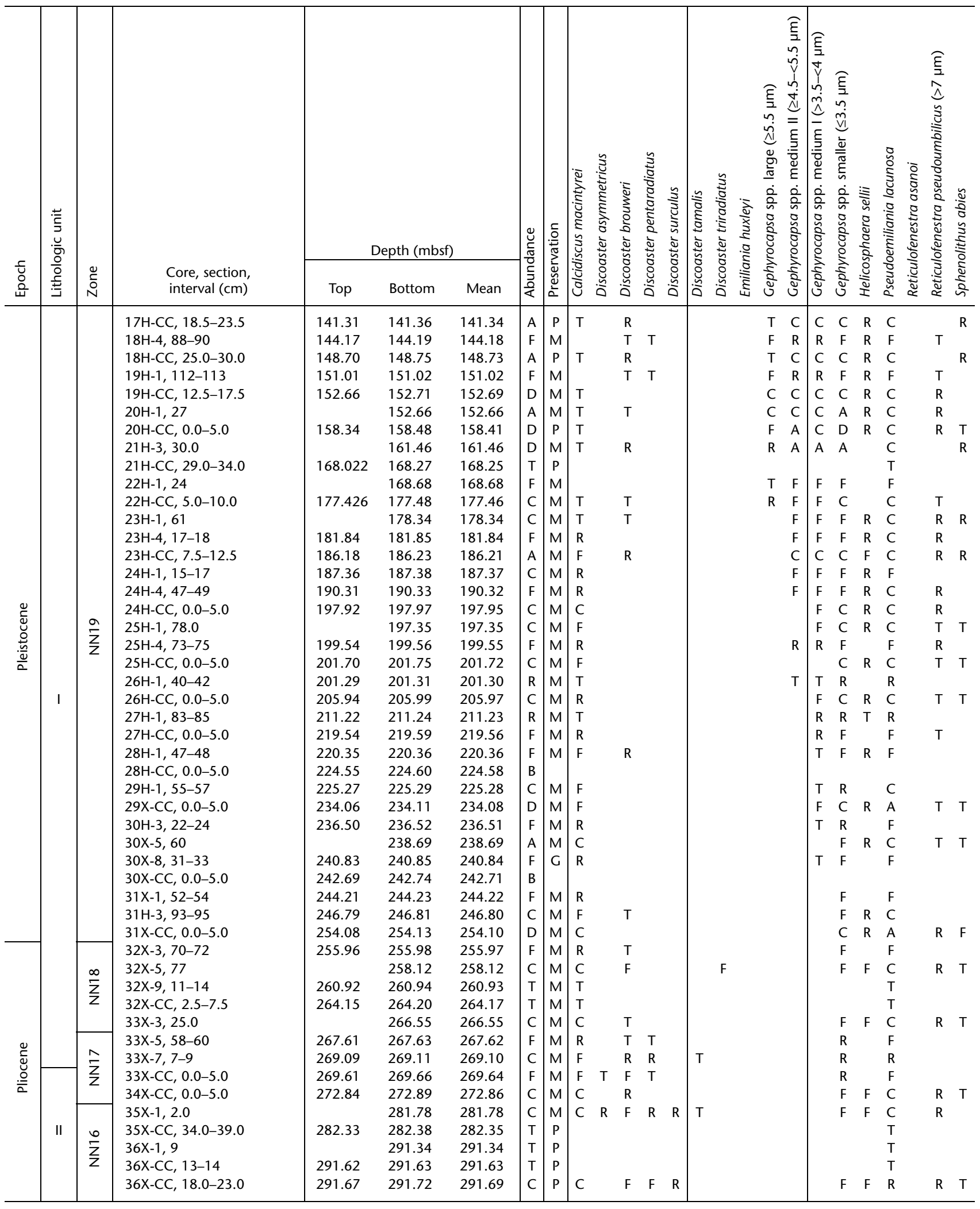

Abundance: $\mathrm{D}=$ dominant, $\mathrm{A}=$ abundant $\mathrm{C}=$ common, $\mathrm{F}=$ few, $\mathrm{R}=$ rare, $\mathrm{T}=$ trace, $\mathrm{B}=$ barren. Preservation: $\mathrm{G}=$ good, $\mathrm{M}=$ moderate, $\mathrm{P}=$ poor. 


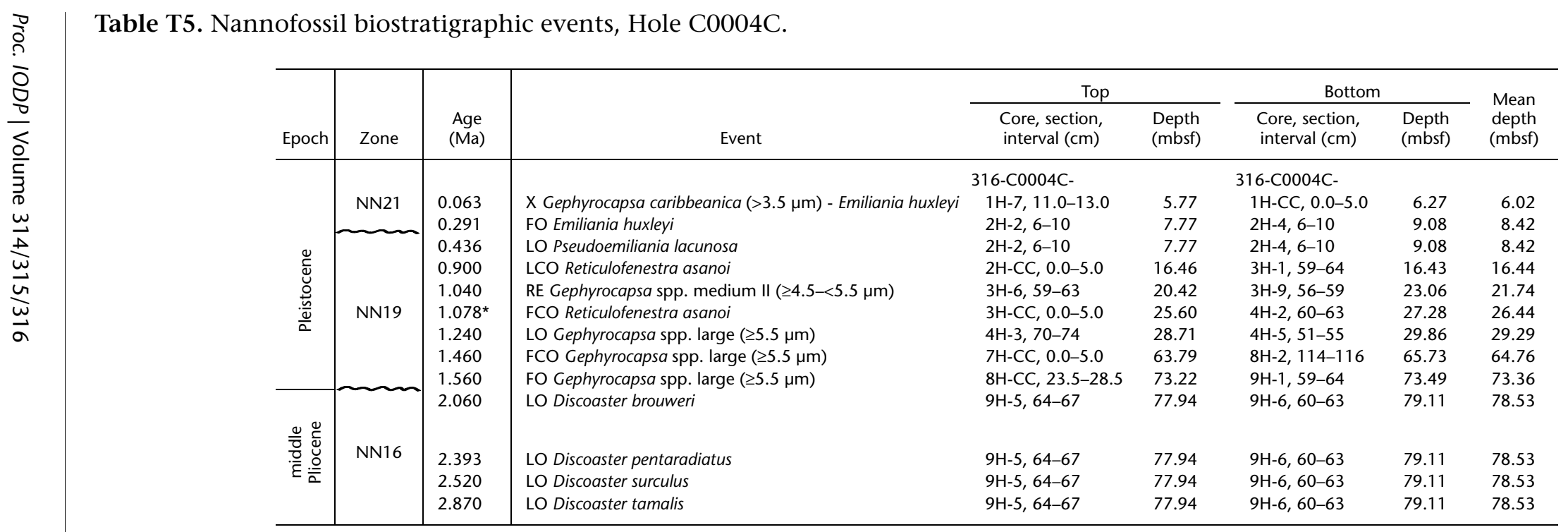

$\mathrm{X}=$ crossover in abundance, $\mathrm{RE}=$ reentrance, $\mathrm{FO}=$ first occurrence, $\mathrm{FCO}=$ first consistent occurrence, $\mathrm{LO}=$ last occurrence, $\mathrm{LCO}=$ last consistent occurrence . 


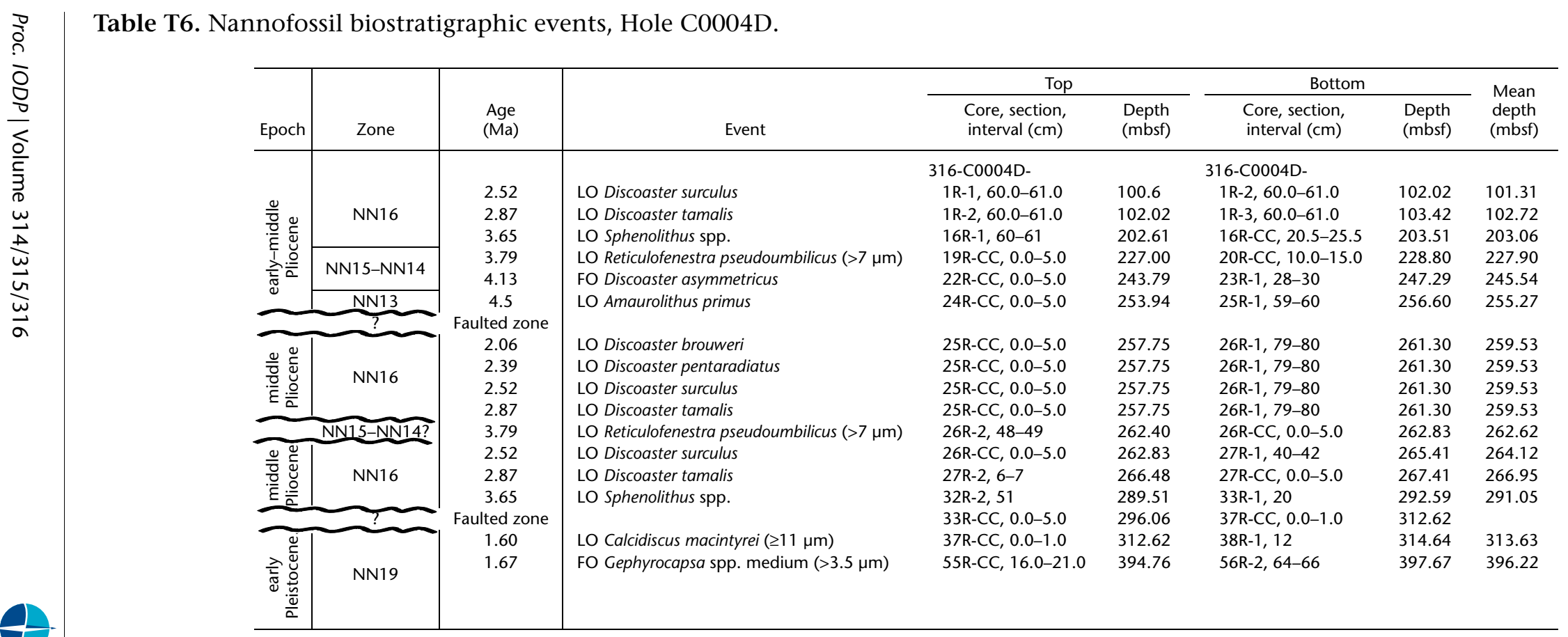

FO = first occurrence, $L O=$ last occurrence. 
Table T7. Nannofossil biostratigraphic events, Hole C0008A.

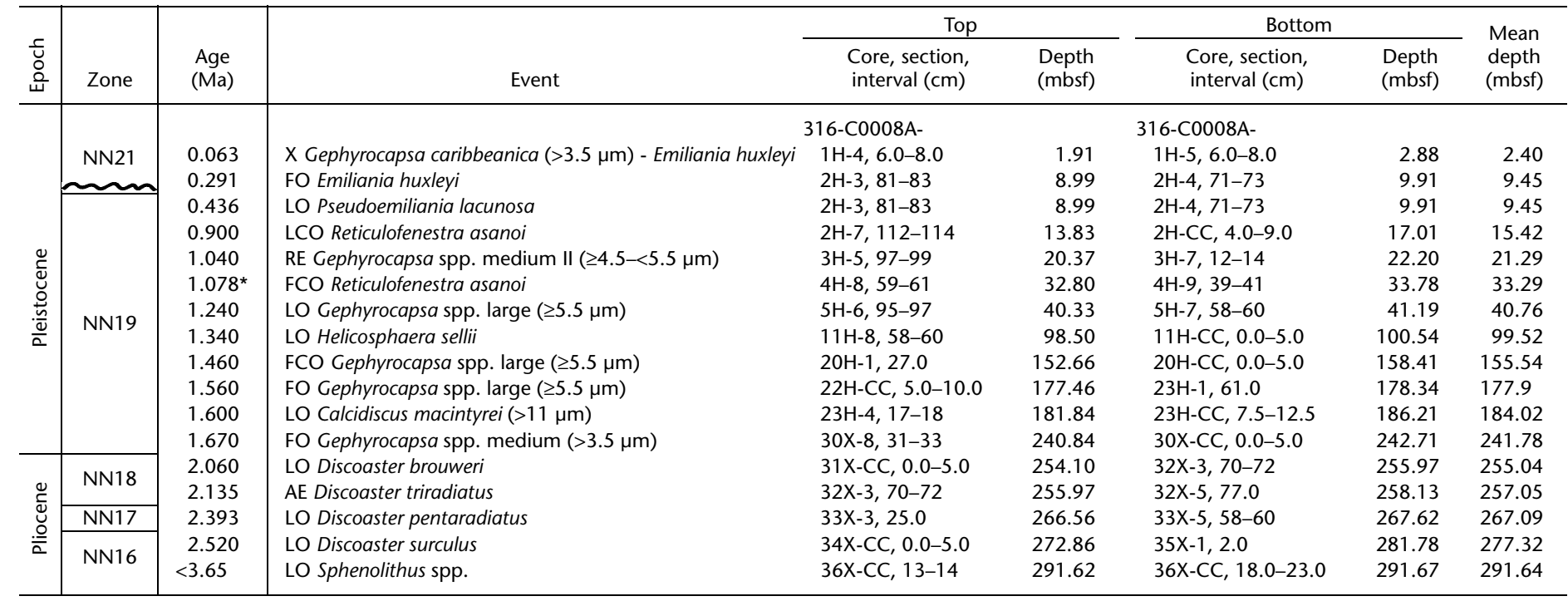

${ }^{*}=$ datum based on Atlantic or Mediterranean records. $\mathrm{X}=$ crossover in abundance, $\mathrm{RE}=$ reentrance, $\mathrm{AE}=\mathrm{acme}$ end, $\mathrm{FO}=$ first occurrence, $\mathrm{FCO}=$ first consistent occurrence, $\mathrm{LO}=$ last occurrence, $\mathrm{LCO}=$ last consistent occurrence. 